\title{
Политика и высшее военное образование в Боснии и Герцеговине: упущенные возможности
}

\author{
Хайни Вечера*
}

\section{Введение}

Развитие высшего военного образования неотделимо от целостного развития современных вооруженных сил. Это развитие обычно отражает приспосабливание к изменениям во внешнем стратегическом окружении, изменениям в военной технологии и доктрине, и изменениям в социальном окружении вооруженных сил.

Это верно для вооруженных сил, у которых нет прерывания традиции, тогда как для вооруженных сил, развитие которых было прервано историческими событиями, схема является другой. В этой статье рассматривается ситуация в Боснии и Герцеговине (БиГ), которая сама по себе является уникальной. Конкретная политическая ситуация в Боснии и Герцеговине после распада Югославии, последовавшая война в период 1992-1995 года и Общее рамочное соглашение о мире (Дейтонские соглашения) от декабря 1995 года привело к весьма децентрализованной структуре государства с двумя весьма автономными политическими «образованиями», каждое из которых сохранило вооруженные силы, созданные во время войны, что de facto привело к военному разделению БиГ. Таким образом, когда Запад инициировал процесс военных реформ в БиГ в 2002 году, они, в первую очередь, были направлены на установление государственного контроля этих вооруженных сил (2003), и затем на их слияние в единые вооруженные силы страны (2005), причем все другие проблемы отошли на второй план.

Подобным образом обстояли дела и с военным образованием. Хотя согласованная система образования и квалификации новых объединенных государственных вооруженных сил БиГ была бы ключевым элементом завершения реформ в сфере обороны, таковой еще не было. Были серьезные попытки, но на данный момент все они не имели успеха. Поэтому в этой статье будут:

Доктор Хайнц Вечера, бригадный генерал в отставке, работал исследователем и лектором в Австрийской национальной академии обороны (АНАО) и адъюнкт-профессором в Венском университете. Он так же является приглашенным преподавателем в Балтийском колледже обороны. Во время своих назначений в Боснии и Герцеговине он был членом Комиссии по реформе обороны (2003) и с 2007 по 2012 год был академическим лектором в Центре подготовки для участия в операциях по поддержанию мира (ЦПУОПМ). Эта статья основана на опыте автора, накопленного в период его участия в процессе реформ с 2007 по 2012 год, и выражает его персональную точку зрения. Она не выражает позиции или политику министерств обороны Австрии, Боснии и Герцеговины или Объединенного королевства, ЦПУОПМ, Австрийской национальной академии обороны, Консорциума ПРМ или журнала Взаимосвязи.

Единственным исключением было установление демократического парламентарного контроля вооруженных сил. 
- Вкратце обрисована политическая и военная ситуация в БиГ, в том числе и отсутствие согласованной системы военного образования

- Представлены первые инициативы в контексте реформ в сфере обороны, а также вне ее

- Обрисованы инициативы, предпринятые для учреждения институций высшего военного образования, и противодействие, которое они встретили

- Оценен процесс с учетом его последствий, в том числе и причины его неуспеха.

\section{Ситуация в Боснии и Герцеговине}

Распад бывшей Социалистической Федеративной Республики Югославия (СФРЮ) означал и распад бывшей Югославской Народной Армии (Jugoslovenska Narodna Armija или ЮНА $)^{2}$ и создание национальных вооруженных сил унаследовавшими СФРЮ государствами. Тогда как Сербия унаследовала в основном нетронутую военную систему ЮНА (в том числе и высококачественную военную академию), отделившиеся государства ${ }^{3}$ в большинстве случаев добились своего суверенитета в результате войн за независимость, ${ }^{4}$ и оказались с вооруженными силами в основном произошедших из территориальной системы обороны, но по крайней мере с более-менее когерентной структурой.

В Боснии и Герцеговине война, последовавшая за декларацией независимости в апреле 1992 года, была как войной для отделения от Югославии, так и войной между тремя основными этническими группами в БиГ (боснийцами, или боснийскими мусульманами, сербами и хорватами), с одновременной интервенцией со стороны соседних Сербии и Хорватии. ${ }^{5}$

Война между боснийцами и хорватами закончилась, когда при посредничестве Соединенных Штатов в 1994 году между ними была создана «Федерация». После интервенции Запада в 1995 году сербы также согласились на прекращение огня, что тогда привело к тому, что в конце 1995 года все участвующие стороны подписали «Общее рамочное соглашение о мире» («Дейтонские мирные соглашения», или ДМС). ДМС создали весьма децентрализованную государственную струк-

2 Хотя СФРЮ не была членом Варшавского договора, ее вооруженные силы с некоторыми исключениями базировались на партизанских традициях и восточных моделях, что проявлялось, главным образом, в ее доктринах и структурах.

3 Как Словения, Хорватия и Бывшая Югославская Республика Македония (БЮРМ), но так же и Босния и Герцеговина при еще более специфических условиях (смотри ниже). Кроме как независимость БЮРМ (1991) и Черногории (2006).

«Этнические» отличия этих групп в меньшей степени являются языковыми, чем религиозными. Боснийцы (приблизительно 45\% населения) являются мусульманами; сербы (приблизительно 33\%) - православными христианами; хорваты (приблизительно 17\%) римокатоликами. Все данные основаны на переписи населения от довоенного 1991 года; надежные данные после объявления независимости трудно найти, так как с тех пор переписи населения не проводилось. 
туру, ${ }^{6}$ с двумя очень автономными политическими субъектами - (мусульмано-хорватская) Федерация Боснии и Герцеговины и (доминированная сербами) «Республика Сербская». ${ }^{7}$ Далее, ДМС позволили этим двум субъектам сохранить свои военно-временные вооруженные силы. Таким образом, в течении десяти лет в рамках одного государства существовали две отдельные армии, неявно настроенные друг против друга, и следующие разным моделям доктрин и образования. ${ }^{8}$ Только в 2002 году был начат процесс, который поэтапно привел к созданию единых вооруженных сил в 2006 году.

\section{Отсутствие когерентной системы военного образования и его влияние на ситуацию в вооруженных силах}

Во время вооруженного конфликта, который продолжался с 1992 по 1995 год, у участвующих армий не было своей системы образования и квалификации. ${ }^{9}$ В отдельных армиях Федерации Боснии и Герцеговины и Республики Сербской это положение сохранилось и после мирных соглашений. Квалификация и образование часто обеспечивались аутсорсингом в страны, с которыми имелись политические связи, что в свою очередь позволяло этим странам оказывать определенное идеологическое или политическое влияние на соответствующие факторы в БиГ. ${ }^{10}$

Вооруженные силы Республики Сербской ${ }^{11}$ рассчитывали в основном на Федеральную Республику Югославию (ФРЮ) - в состав которой входили бывшие югославские республики Сербия и Черногория, - но некоторые офицеры проходили обучение и в Греции. ${ }^{12}$ Квалификация офицеров РС на деле более-менее следовала схемам, существующим в бывшей ЮНА.

В Федерации подготовка в основном велась в БиГ по поддерживаемой США программе «Готовить и оборудовать», которая была нацелена на создание запад-

6 Конституция Боснии и Герцеговины закреплена в мирном договоре как одно из приложений (Приложение 4). Таким образом, Босния и Герцеговина является государством с навязанной извне конституцией.

7 Сама Федерация в свою очередь была разделена на десять кантонов с высокой степенью автономности в таких сферах как образование, полиция, правосудие и т.д.

8 Тогда ситуацию описывали таким образом: «единственным возможным врагом боснийского солдата является другой боснийский солдат».

9 На некоторое время каждая этническая группа (боснийцы, хорваты и сербы) имела свою собственную армию. Армии боснийцев и хорватов слились в одну только при учреждении поддерживаемой США Федерации в 1994 году.

10 Концепция карьерного развития офицеров генерального штаба БиГ (Koncept profesionalnog razvoja časnika OS BiH) указывает, что офицеры нынешнего личного состава получили образование более, чем на 630 курсах и в не менее, чем 55 странах.

11 Vojska Republike Srpske/VRS (Армия Республики Сербской [сербский субъект в БиГ]).

12 Все данные приведены согласно работе бригадного генерала в отставке Алена Ламбалла, старшего советника главы миссии [ОБСЕ] по вопросам академических военных институций, Training of Officers of the Armed Forces in Bosnia and Herzegovina and of Civilians on Defence and Security Issues (Sarajevo, 2002), 9. 
ной, совместимой с системой НАТО, системы образования и квалификации. В институциональном плане было учреждено Командование по подготовке и доктринам (КПД) с подчиненными формированиями. ${ }^{13}$ По сути, квалификация и образование имели западную ориентацию и основывались на переводах документов США. ${ }^{14}$ Существовал, однако, и аутсорсинг подготовки, причем боснийцев посылали в основном в Турцию и другие мусульманские страны - Пакистан, Малайзию и Объединенные Арабские Эмираты. Некоторых хорватов посылали на учебу в Хорватию. Дополнительно, офицеров из вооруженных сил Федерации посылали в страны НАТО и ПРМ. ${ }^{15}$

В одном анализе, проведенном в то время, было сделано заключение, что в сфере подготовки «нет никаких связей между армиями субъектов. Организации, в которых осуществляется подготовка в Федерации и РС, никогда не обмениваются опытом. Они друг друга игнорируют». ${ }^{16}$

\section{Реформы в сфере обороны и военное образование}

Чтобы преодолеть это разделение, в 2002 году западные акторы в БиГ инициировали процесс реформ в сфере обороны, который официально начался в 2003 году. Это привело, на первом этапе, к установлению системы командования и управления на государственном уровне в 2004 году, ${ }^{17}$ и на втором этапе, в 2006 году, ${ }^{18}$ к созданию единой, под управлением государства, армии Боснии и Герцеговины.

\section{Работа Комиссии по реформам в секторе оборонь}

Вопросами военного образования занялись на втором этапе процесса реформ (2004-05). В Рабочей группе 2 были подготовлены несколько рабочих презента-

13 Центр профессионального развития (ЦПР), Центр боевых симуляций и разные центры набора военнослужащих.

14 Lamballe, Training of Officers of the Armed Forces in Bosnia and Herzegovina, 3-4.

15 Там же, 8.

16 Там же, 7.

17 На этом этапе Федерация и Республика Сербская поддерживали свои собственные вооруженные силы, которые, однако, были приведены под единое государственное командование и управление $\left(\mathrm{C}^{2}\right)$ принятием соответствующих государственных законов, созданием министерства обороны, генерального штаба и оперативного командования. Смотри доклад комиссии по реформам в обороне, The Way to Partnership for Peace (Sarajevo, 2003). Автор принимал участие в работе комиссии на первом этапе.

18 Тем самым полностью отменив вооруженные силы субъектов; смотри Окончательный доклад Комиссии по реформам в секторе обороны, A Single Army for the $21^{\text {st }}$ Century (Sarajevo, 2005). 
ций ${ }^{19}$ и рабочих докладов, ${ }^{20}$ которые практически предвидели идеи, выдвинутые Комиссией по квалификации офицеров Министерства обороны (МО) после 2008 года. ${ }^{21}$ Однако, эти предложения не нашли места в докладе Комиссии по реформам в секторе обороны (КРСО).

Была высказана даже оценка, что реформы в секторе обороны имели отрицательный эффект, что «одним из минусов реформ в обороне было приостановление многих программ подготовки, в том числе для новых офицеров и солдатов ...». ${ }^{22}$ Ситуация оставалась проблематичной, так как офицеры новой объединенной армии не имели общей образовательной основы, что затрудняло совместные операции и штабную работу. ${ }^{23}$ Отсутствие совместной практической подготовки и образования в вооруженных силах БиГ препятствовало развитию истинно совместного esprit de corps. Таким образом, эффект реформ в секторе обороны уменьшался изза отсутствия совместного образования и практической подготовки в вооруженных силах БиГ. Такая общая основа была бы критическим элементом в стремлении утвердить реформы, так как хорошо организованные вооруженные силы немыслимы без хорошо организованного образования.

\section{Инициативы, параллельные реформам в секторе обороны}

Направленные на осуществление совместного военного образования инициативы были задействованы приблизительно в то самое время, когда начались и реформы в обороне, но очень изолированно. Еще в 2001 году Совместный командно-штабной колледж Объединенного королевства предпринял «Исследование осуществимости учреждения Совместного лидерского колледжа для вооруженных сил Боснии и Герцеговины. ${ }^{24}$ Предполагалось, что наиболее подходящим было бы начать обучение и практическую подготовку для участия в операциях по поддержанию мира. Это заполнило бы некоторые пробелы в подготовке, касающиеся операций по поддержанию мира (ОПМ), но так же позволило бы начать совместное обуче-

19 Генерал-майор в отставке Джон Древиенкиевич, тогда директор департамента сотрудничества в сфере безопасности Миссии ОБСЕ; заместитель председателя КРСО и председатель РГ2, «Требования к образованию и квалификации», PowerPoint презентация (число не указано). Автор получил отпечатанную копию из департамента сотрудничества в сфере безопасности Миссии ОБСЕ.

20 РГ2 КРСО, «Будущее индивидуальное образование и квалификация в ВС БиГ - концептуальный доклад», проект доклада (21 сентября 2005).

21 Смотри ниже. Это не совпадение, так как Древиенкиевич так же составил концептуальный документ для этого семинара.

${ }^{22}$ Ken Lindsay, "Memorandum on Military Education and Doctrine in the AF BiH," NATO Transition Management Group (10 May 2007).

23 За исключением уменьшающегося числа тех систематически подготовленных в довоенной ЮНА.

24 Joint Services Command and Staff College, "Study into the Feasibility of Establishing a Joint Leadership College for the Armed Forces in Bosnia and Herzegovina," BTSR/01/01, 29 April 2002. 
ние раздельных вооруженных сил Федерации Боснии и Герцеговины и Республики Сербская.

В результате в 2003 году был учрежден Центр подготовки для участия в операциях по поддержанию мира (ЦПУОПМ). Его первой задачей было обеспечить совместную подготовку военнослужащих БиГ для участия в операциях по поддержанию мира. ${ }^{25}$ Второй целью, однако, было обеспечить совместное образование и практическую подготовку в принципе, в ожидании объединения раздельных вооруженных сил. ${ }^{26}$ Центр был учрежден как международная институция sui generis группой государств с одинаковыми взглядами и руководством. Персонал состоял из сотрудников, содержание которых оплачивалось этими государствами и вооруженными силами БиГ. ${ }^{27}$ Должности начальника и директора по обучению (ДО, который на деле был заместителем начальника) с самого начала были международными должностями. Предвиделось, что центр сохранит международный характер на следующие десять лет (2003-2013). К тому времени центр должен перерасти в штабной колледж и быть передан в управление вооруженным силам БиГ. ${ }^{28}$

\section{Элементы военного образования после реформ в секторе обороны}

Со слиянием отдельных вооруженных сил в единую армию БиГ бывшее КПД армии Федерации стало государственной институцией. Были разработаны разные курсы, в том числе четырехмесячный штабной курс, причем вся подготовка осуществлялась в Боснии. С другой стороны, сразу после создания ЦПУОПМ, в нем был разработан курс операций по поддержанию мира для младшего состава, который сочетал подготовку штабных офицеров и специальную подготовку для участия в операциях по поддержанию мира. Подготовка велась исключительно на английском.

Другие курсы разрабатывались вне вооруженных сил, такие как курс для военных атташе, предлагаемый Женевским Центром Политики Безопасности (ЖЦПБ),

25 Параграф 1 описания миссии ЦПУОПМ гласит: «Обеспечивать международно одобренные образование и практическую подготовку для избранных младших офицеров вооруженных сил Боснии и Герцеговины и приглашенных международных студентов, которые будут руководить и готовить других служащих в международных гуманитарных операциях и операциях по поддержанию мира».

26 Параграф 2 описания миссии ЦПУОПМ гласит: «Разрабатывать новые курсы и семинары, которые необходимы вооруженным силам Боснии и Герцеговины или другим компонентам сектора безопасности БиГ».

27 В начале отдельными вооруженными силами двух автономных субъектов (Федерации и Республики Сербской), затем объединенными вооруженными силами БиГ.

28 Еще в марте 2006 года тогдашний ДО ЦПУОПМ говорил, что «в перспективе [ЦПУОПМ] превратится в командно-штабной колледж ВС БиГ и будет передан властям БиГ в качестве подарка. Смотри протоколы заседания «Академическое сотрудничество ЦПУОПМ и Сараевского университета», факультет политических наук, встреча № 2-2006 (8 марта 2006). Будущие функции на том этапе, похоже, были вне сомнений, что потом изменилось. 
или семинары по политике безопасности, организованные миссией ОБСЕ в Боснии и Герцеговине. Так же несколько университетов в БиГ добавили в свои учебные планы дисциплины с ориентацией на политику безопасности. ${ }^{29}$ Все эти действия, однако, предпринимались совершенно независимо друг от друга. Хотя их и можно рассматривать как некую обозначившуюся схему высшего военного образования, вряд ли их можно назвать системой.

\section{Окно возможностей открывается}

Практически одновременно с реализацией процесса реформ в сфере обороны в октябре 2006 года состоялись выборы, и было назначено новое правительство в 2007 году. Министром обороны стал Селмо Цикотич, бывший кадровой офицер, который сделал академическую карьеру. Его заявленными целями были продолжение курса на принятие БиГ в члены НАТО и создание системы военного образования и квалификации. Он инициировал процесс создания организованной системы военного образования и расширения ЦПУОПМ в военный колледж с полной академической аккредитацией.

Для этого он добился, чтобы эксперт из Австрийской национальной академии обороны (АНАО) - автор этой статьи - присоединился к ЦПУОПМ в качестве академического лектора и был в расположении для развития системы высшего военного образования. Эксперт предложил оптимальное сочетание профессионального и академического опыта, десятилетия работы в стране, в том числе и участие в КРСО. После недолгих переговоров я присоединился в качестве академического лектора в конце 2007 года.

После некоторой подготовительной работы в близком сотрудничестве с консультативной группой НАТО при МО БиГ, министр принял решение от 24 марта 2008 года о создании рабочей группы «для образования и практической подготовки офицеров вооруженных сил БиГ», называемой Комиссией по военному образованию и квалификации. ${ }^{30}$ Комиссия имела широкий круг участников и ей было поручено разработать единую концепцию образования и практической подготовки для ВС БиГ. ${ }^{31}$

В качестве первого шага на семинаре в начале апреля 2008 года группа сосредоточилась на Базовой подготовке офицеров (БПО). ${ }^{32}$ Результаты обсуждений

29 Как, к примеру, университеты в Сараеве, Баня Лука и Бихаче.

30 No. 10-33-2-1328-1/08.

31 В число участников входили эксперт по высшему образованию из миссии Совета Европы в Сараево, который выразил надежду, что академически аккредитированное профессиональное военное образование как государственное начинание одновременно приведет к преодолению в принципе политической фрагментации высшего образования в БиГ.

32 Основой обсуждений был концептуальный документ, разработанный генерал-майором в отставке Древиенкиевичем: «Концептуальный документ относительно формирования системы высшего военного образования, переданный рабочей группе, сформированной решением МО Боснии и Герцеговины», no. 10-33-2-1328-4/08 (24 марта 2008). 
группы были переданы министру обороны и впоследствии были трансформированы в политические решения. Первые кадеты, готовящиеся к получению офицерского звания, должны были начать обучение в конце 2009 года.

В июле 2008 года министр обороны попросил меня написать концептуальный документ относительно высшего военного образования, охватывающего требования к курсам, образовательным институциям и интегрирования существующих курсов и институций в единую согласованную систему. Документ был передан министру в конце осени 2008 года. В нем анализировались требования и возможности для реализации высшего военного образования в Боснии и Герцеговине и предлагалась когерентная структура курсов, начиная с штабного офицерского и кончая курсом стратегического лидерства. Предполагалось, что высшее военное образование должно быть совместимо с академическим образованием в гражданском секторе. Институциональную рамку для большинства курсов (кроме курсов для младшего состава) могла обеспечить Академия обороны Боснии и Герцеговины, которая была бы совместима с подобными институциями в других странах. Создание как курсов, так и институций можно было бы реализовать на базе существующих «прекурсоров», как например ЦПУОПМ.

\section{В открытое окно дует холодный ветер}

Хотя как первоначальные намерения министра, так и концептуальный документ предоставляли ЦПУОПМ важную роль в будущем высшем военном образовании, эта идея не нашла поддержки у нового руководства ЦПУОПМ. Первый начальник ЦПУОПМ явным образом поддерживал идею развития ЦПУОПМ и превращения его в оборонный колледж академического характера - концепция, которая имела место до марта 2006 года. ${ }^{33}$ Однако, его преемник, который принял центр в 2007 году, придерживался более традиционного подхода. Во-первых, он делал упор на аспект «практической подготовки», и конкретно в тесной области операций по поддержанию мира. Хотя он успешно работал для утверждения ЦПУОПМ в качестве регионального центра подготовки, ${ }^{34}$ но в то же время уделял меньше внимания завершению реформ в секторе обороны путем учреждения системы высшего

33 Первым начальником ЦПУОПМ был датский бригадный генерал, который занимал эту должность с 2003 по 2006 год. Во время его мандата будущая роль ЦПУОПМ как командно-штабного колледжа ВС БиГ не оспаривалась. Смотри выше цитату из протокола встречи «Академическое сотрудничество между ЦПУОПМ и Сараевским университетом» от марта 2006 года о том, что ЦПУОПМ будет трансформирован в командноштабной колледж ВС БиГ. Как пример академических амбиций центра, он ввел в программу исследовательский реферат, известный как «реферат начальника», который должны были делать слушатели. Он был отменен его преемником как «слишком академический» и введен заново следующим начальником ЦПИОПМ, который был из БиГ.

34 ЦПУОПМ получил аккредитацию как «Квалификационный и образовательный центр ПРМ» в 2008 году и позже был признан одним из трех центров ПРМ повышения квалификации в Юго-восточной Европе. 
военного образования. ${ }^{35}$ Во-вторых, в том же плане он ставил под вопрос ценность академических степеней в военном образовании. ${ }^{36}$ В третьих, у него были сложности в абстрагировании себя от своего национального происхождения. ${ }^{37}$ И последнее, у него были проблематические отношения с принимающей страной, ${ }^{38}$ в частности, с вооруженными силами БиГ и их зарождающейся системой образования, которые он рассматривал больше как соперников, чем как будущих бенефициариев работы ЦПУОПМ. ${ }^{39}$ Это отношение, в свою очередь, привело к нарастанию враждебности со стороны БиГ, в частности со стороны КПД не только по отношению к начальнику лично, но и к ЦПУОПМ как институции. И последнее, когда я закончил концептуальный документ для министра обороны, начальник цен-

35 Когда идея трансформирования ЦПУОПМ в будущий колледж обороны страны была еще на стадии обсуждения, начальник отмел эту идею замечанием, что страна «слишком маленькая для такого требования», и что им «следует идти в Белград - Военная академия там достаточно большая, чтобы принять всех», полностью игнорируя политическую основу войн для отделения, которые в большой степени были вызваны централистскими тенденциями в Белграде.

36 Еще в 2008 году я добился консенсуса среди всех восьми государственных университетов в БиГ, что они примут учебный план штабного курса ЦПУОПМ как часть регулярного курса по менеджменту. Имея в виду политическую и этническую фрагментацию образовательной системы БиГ (пять университетов являются боснийскими/ мусульманскими, два - сербскими/православными и один - хорватским/католическим), это было бы политическим прорывом, который вымостил бы путь к академически аккредитированному профессиональному военному образованию, принимаемому всеми тремя этническими группами. Это предложение, однако, было растоптано начальником Центра, который цитировал высказывание своего национального начальника генерального штаба, что «нам нужны солдаты, а не академики».

37 Он часто прибегал к своему национальному опыту как единственному ориентиру, например, когда отрицал необходимость юридической службы в вооруженных силах «так как все равно у нас ее нет» - высказывание, которому резко воспротивился член личного состава из США, который указал на их систему юридических услуг. Этому мнению начальника Центра последовал, и даже превзошел ДО из Объединенного Королевства, который так и не смог выбраться из своего национального пузыря.

К примеру, когда его пригласили принять участие в семинаре, организованном разведывательным отделом объединенных вооруженных сил, он отказался от участия, приводя в качестве аргумента: «Мы с ними не разговариваем».

39 К примеру, он предлагал, чтобы Центр повышения профессиональной квалификации КПД перестал вести штабной курс, так как он дублировал бы курс в ЦПУОПМ. Хотя это предположение было верно по существу, оно раскрывало некое противоречие. С одной стороны он не был согласен, чтобы ЦПУОПМ имел национальные функции (в частности в высшем военном образовании), но с другой он рассматривал национальные усилия ЦПК в этом направлении как конкурирующие его собственной институции. Должны были существовать кооперативные решения, которые могли бы разрешить это видимое противоречие, например двухэтапный подход, который предлагался в моем концептуальном документе. Первый этап, это «национальный» штабной курс на национальном языке для всех отвечающих требованиям офицеров, и затем выборочный международный штабной курс на английском в ЦПУОПМ. 
тра напрямую воспротивился министру, и успокоился только после того, как министр заверил его, что документ не направлен против ЦПУОПМ и предложил ему роль в разработке стратегического командно-штабного курса (СКШК) для БиГ.

\section{Семинары по высшему военному образованию}

На основе концептуального документа и параллельных исследований, проведенных МО, консультативная группа НАТО организовала семинар в февраля 2009 года. Он был задуман как продолжение на основе результатов последнего семинара по БПО с целью содействовать созданию системы высшего военного образования. Программа семинара основывалась на первичном докладе генерал-майора Древиенкиевича и на моем концептуальном документе. ${ }^{40}$ Использовался комплексный подход, охватывающий вопросы карьерного развития в вооруженных силах БиГ, предполагаемой структуры курсов, институциональных требований и будущей роли ЦПУОПМ. Выводы семинара в основном следовали первичному докладу. ${ }^{41}$ Настоятельно рекомендовалось учреждение колледжа обороны БиГ в качестве институции высшего военного образования, тогда как Центр КПД повышения профессиональной квалификации занимался бы курсами более низкого уровня.

\section{Последуюшие шаги}

В результате семинара Министерство обороны поручило ЦПУОПМ разработать командно-штабной курс, который заканчивался бы присваиванием степени магистра. Для этой цели МО и ЦПУОПМ в мае 2009 года договорились создать проектную и направляющую группы. Далее, ЦПУОПМ должен был разработать проект документа, подготавливающего решение коллективного триэтнического президентства БиГ об учреждении колледжа обороны. Центр так же должен был информировать страны-партнеры ЦПУОПМ о текущем развитии дел. В результате ЦПУОПМ создал четкую организацию планирования для предполагаемого командного и генерал-штабного курса, включающего и его академическую аккредитацию, и трансформацию центра в колледж обороны БиГ. Дополнительно предстоящее участие ЦПУОПМ в коллективе по разработке типовой программы ПВО рабочей группы Консорциума по развитию образования дало бы возможность БиГ приобрести информацию, которая позже была бы полезна для создания собственной учебной программы.

40 Смотри MG (ret.) John Drewienkiewicz, "Strawman Paper on Professional Officer Development and Training in the Armed Forces of Bosnia and Herzegovina," paper written for the NATO HQ Sarajevo (4 Feb 2009).

41 "Polazni dokument o profesionalnom razvoju oficira i obuci u Oružanim snagama Bosne i Hercegovine; Dokument napisan za Ministarstvo odbrane BiH, 3 Mart 2009” («Вводный документ по профессиональной квалификации офицеров и практической подготовке в вооруженных силах Боснии и Герцеговины. Документ предназначен для министерства обороны БиГ, 3 марта 2009 года»). 
И последнее, в конце 2009 года международный (и скептически настроенный) начальник ЦПУОПМ был заменен офицером из БиГ с оптимальной для этой должности квалификацией. У него была впечатляющая военная карьера, заграничный опыт и опыт в ЦПУОПМ (где он был начальником штаба), с академическими квалификациями, со степенью доктора в области политических наук и опытом лектора в Сараевском университете. Таким образом, в 2010 году наконец сложились оптимальные условия для создания системы высшего военного образования в Боснии и Герцеговине, на базе предыдущей работы комиссий и разнообразных, но весьма когерентных концептуальных документов.

\section{Окно закрывается}

Серия семинаров была продолжена в мае 2010 года, но без участия консультативной группы НАТО или других внешних экспертов. ${ }^{42}$ Генеральный штаб представил когерентный доклад, касающийся в целом вопросов профессионального развития офицеров, включая профессиональное развитие и образование. Доклад следовал в общем линии предыдущих семинаров. ${ }^{43}$ Во время встречи, однако, обозначилась растущая поляризация между «старым мышлением» и «новым мышлением», и не без связи с предстоящей выборной кампанией. ${ }^{44}$ Независимо от этого, семинар разработал перспективную, хорошо структурированную образовательную систему с четким намерением часть обучения вести на английском и получить академическую аккредитацию в области высшего военного образования.

Однако, мало что из этого нашло отражение в следующем варианте доклада. ${ }^{45}$ Вообще не упоминались отдельные институции ВВО, и он отдавал предпочтение КПД и подчиненным ему формированиям. ${ }^{46}$ Следующая версия доклада, от марта

42 Я участвовал в этих семинарах скорее в качестве академического лектора ЦПУОПМ, чем в качестве эксперта.

43 Bosnia and Herzegovina, Ministry of Defense, AF BiH Joint Staff, "Concept of AF BiH Professional Development" (draft),May 2010.

44 Эта поляризация проявилась, к примеру, в отношении вопроса академической аккредитации BВО, или по вопросу, какая часть программы должна предлагаться на английском.

45 Босния и Герцеговина, министерство обороны, Объединенный штаб ВС БиГ, “Коncept profesionalnog razvoja oficira OS BiH (nacrt)/ Концепция ВС БиГ профессионального развития (проект), май 2010. Хотя на второй версии тоже указано «май 2010», она определенно отличается от документа, цитированного выше, и была распространена только в июне.

46 Термин, использованный в докладе, был «Училище командования и генерального штаба». Этот компромисс мог быть результатом отказа сербской стороны принять такие термины как «Академия обороны», «Колледж обороны», «Штабной колледж» и подобные им. 
2011 года, шла даже дальше, сосредотачивая внимание исключительно на КПД и только вскользь упоминая академическую аккредитацию. ${ }^{47}$

Причины этого существенного сдвига можно найти в развитии политической ситуации. В мае 2010 года началась предвыборная кампания для национальных выборов (они должны были состояться в октябре). Сербская сторона воспротивилась какому бы то ни было дальнейшему развитию государственных институций, ${ }^{48}$ и идея учреждения новых институций для военного образования стала неприемлемой. ${ }^{49}$ Во-вторых, предположительно существовало определенное сопротивление с хорватской стороны из-за латентного напряжения между министром обороны и хорватской фракцией министерства. ${ }^{50}$ Другие слухи упоминали о личных противоречиях и институциональной ревности в отношении все еще находящегося под международным управлением ЦПУОПМ как о возможной причине для противодействия генерального штаба. Хотя к таким слухам следует относится с осторожностью, само их существование является признаком того, что вопросы не всегда рассматривались с необходимой рациональностью и основательностью, но и что имело место определенное политическое влияние.

И последнее, в 2011 году стало ясно, что Центр профессионального развития КПД становится ведущей институцией. Все карьерные курсы будут проводиться в ЦПР, тогда как ЦПУОПМ ограничится операциями по поддержанию мира. Он мог бы, однако, взять на себя специализированные модули карьерных курсов в ЦПР.

\section{Обзор и выводы}

Развитие высшего военного образования в БиГ похоже застряло на полдороге. После последнего семинара нет никакого видимого прогресса. Так же, когда было сформировано новое правительство в конце 2011 года, новый министр обороны демонстрировал очевидно меньше энтузиазма насчет создания системы высшего военного образования. С передачей в национальную собственность в конце 2012 года ЦПУОПМ будет подчинен КПД, не имея никакой ведущей роли в военном образовании. Хотя уже можно заметить некоторые элементы ПВО, однако, не видно никакого развития ВВО в рамках других институций. Перспектива создания

47 Босния и Герцеговина, министерство обороны, Объединенный штаб ВС БиГ, “Коncept profesionalnog razvoja oficira OS BiH (nacrt)/ Концепция ВС БиГ профессионального развития (проект), март 2011. Эта версия была написана на хорватском (“časnik” вместо "oficir"). О возможных причинах смотри ниже.

48 На более позднем этапе провинциальное руководство Республики Сербской пошло даже дальше и потребовало вообще отменить вооруженные силы.

49 Другой возможной причиной был факт, что академически аккредитированная (т.е. государственного уровня) военная образовательная институция противоречила бы конституционным прерогативам (этнически определенным) субъектов в образовании, которые сербы и хорваты ревниво оберегали.

50 Использование хорватского в этой последней версии можно рассматривать как подтверждение для такого предположения. 
работающей, независимой системы высшего военного образования в БиГ сейчас выглядит весьма удаленной.

Военное образование является предварительным условием для нормального функционирования вооруженных сил, как с технической точки зрения, так и с политической. Это еще более верно в случае с БиГ, где нужно было создать вооруженные силы на государственном уровне, чтобы преодолеть военно-политическое разделение страны. Когерентная система военного образования была бы краеугольным камнем для «Единых вооруженных сил для двадцать первого века». ${ }^{51}$ Выглядит несколько странным то, что сфера образования и квалификации, хотя и была предметом весьма конкретных предложений со стороны КРСО, не нашла место в окончательном докладе.

И наоборот, инициатива Объединенного королевства от 2001 года, за которой последовало учреждение Центра подготовки для участия в операциях по поддержанию мира в 2003 году, была перспективным конкретным проектом, создавшим систему совместной подготовки еще до слияния отдельных вооруженных сил двух субъектов федерации. Эта работа, однако, привела к созданию параллельных структур, причем КПД разработало свою собственную программу подготовки, и к усилению соперничества между двумя институциями.

Это положение могло бы измениться в результате инициативы, предпринятой в 2007 году новым министром обороны, которая открыла окно для возможности создания системы высшего военного образования в БиГ, особенно имея в виду благоприятное стечение обстоятельств в то время. ${ }^{52}$ ЦПУОПМ как международная институция мог бы предложить возможность создать ВВО, стоящее над местными политическими ссорами, и структуру для такого образования еще до передачи его в национальную собственность в 2013 году, делая процесс практически необратимым.

Этого не случилось по нескольким причинам. Первая причина, это продолжающееся политическое противодействие в рамках БиГ, особенно с сербской сто-

51 Оглавление окончательного доклада КРСО в 2005 году.

52 Эти обстоятельства включали:

- Объединение вооруженных сил субъектов и создание когерентных государственных вооруженных сил

- Явно выраженная воля нового министра обороны

- Само существование ЦПУОПМ, который изначально был создан с тем, чтобы со временем быть трансформированным в колледж обороны

- Наличие иностранной экспертизы, готовой поддержать такие усилия (в том числе и академический лектор АНАО, назначенный в ЦПУОПМ, и бывший председатель соответствующей рабочей группы Комиссии по обороне)

- Содействие консультативной группы НАТО в подготовке и организации семинаров. 
роны. ${ }^{53}$ Вторя причина, это борьба между «традиционалистами» и «модернистами», представленными как на международном, ${ }^{54}$ так и на уровне БиГ ${ }^{55}$ Третьей причиной являлся параллелизм (и соперничество) между ЦПУОПМ и ЦПР КПД. Эту проблему можно было бы разрешить в духе сотрудничества, но это не случилось из-за личностей, вовлеченных в конфликт. ${ }^{56}$ И последнее, несколько сильных личностей, участвующих в процессе, решили силой навязать свои взгляды.

Наиболее решительно в то время действовал начальник ЦПУОПМ, который, по моему мнению, противился всем усилиям, направленным на создание полноценной системы высшего военного образования в рамках ЦПУОПМ. ${ }^{57}$ Он игнорировал политические требования поддержать реформы в сфере обороны, отказывался от сотрудничества с КПД и другими институциями в БиГ и отказывался принять, что академическая аккредитация была бы незаменимым интеллектуальным базисом для BВO ${ }^{58}$ И последнее, как раз когда был назначен национальный и более разносторонне мыслящий начальник ЦПУОПМ, окно возможностей начало закрываться. ${ }^{59}$ Вопрос был застигнут волной предвыборной кампании, и после выборов в 2010 году вопрос о ВВО совсем затормозился.

В итоге кажется иронией судьбы, что практически все элементы для создания когерентной системы высшего военного образования в БиГ были налицо, когда окно возможности открылось в начале 2008 года, за исключением желания одного человека. Этот неуспех вдвойне ироничен, поскольку международный характер ЦПУОПМ изначально был задуман как средство для защиты от влияния местной политики в БиГ, которое позволило бы создание ВВО в «нейтральной» среде. Вместо этого международные представители заблокировали развитие этой жиз-

53 Что, однако, можно было бы преодолеть в период «окна возможности». Были признаки со стороны начальника генерального штаба БиГ (сербской национальности), что развитие может продолжиться, если избегать «провокативную терминологию» (к примеру, «Колледж обороны»). Подобное отношение наблюдалось на ранних стадиях реформы в сфере обороны, когда сербская сторона согласилась с концепцией государственного контроля армии, при условии, что такие термины как «Министерство обороны» будут избегаться.

54 С начальником ЦПУОПМ, бывшим «традиционалистом», и двумя иностранными экспертами - «модернистами».

55 С министром обороны, бывшим «модернистом», и большой группой в МО и генеральном штабе, бывшими «традиционалистами».

56 Когда начальник ЦПУОПМ в то время просто отказывал БиГ национальным институциям в способности достичь требуемого качества, начальник КПД обиделся и ответил, начав институциональную войну с ЦПИОПМ.

57 К тому же, его ДО вероятно проводил политику Объединенного королевства в менеджерском совете ЦПУОПМ, которая стала подчеркнуто негативной с момента занятия им этой должности.

58 В дополнение к последствиям, которые успешное развитие ВВО могло иметь на развитие гражданского сектора высшего образования в целом.

59 Новое назначение само по себе, вероятно, было причиной для противопоставления хорватов, которое, inter alia, возможно, привело к остановке процесса. 
ненно важной сферы. ${ }^{60}$ И самым крайним выражением иронии было то, что учреждение ЦПУОПМ как прекурсора полноценной военной образовательной институции было инициативой Великобритании, ${ }^{61}$ а с 2007 года представитель Объединенного королевства был одним из самых громогласных членов, которые были против создания колледжа обороны. ${ }^{62}$

Как и в другие моменты военной истории, случалось так, что одна личность поворачивает битву от возможного успеха к поражению. Перспектив для поправки нанесенного вреда в ближайшем будущем не видно. Был шанс создать систему высшего военного образования для завершения ПВО в БиГ, но этот шанс был упущен, со всеми проистекающими из этого политическими последствиями.

В итоге, эта важная проблема поднимает вопрос о подборе персонала, назначаемого на такие должности. Хорошая военная квалификация является необходимым условием, но не достаточным. При выборе кандидатов на занятие таких чувствительных международных позиций, страны должны включить такие критерии как культурная осведомленность, понимание политических последствий различных линий поведения, современное понимание образования и широта взглядов с тем, чтобы избежать подобных провалов в будущем.

60 А именно, датский начальник и британский директор по обучению.

61 А именно на основании доклада Командно-штабного колледжа родов войск Великобритании в 2001 году.

62 Согласно информации, полученной от участника в соответствующих сессиях, представитель Объединенного королевства постоянно угрожал приостановить финансовый взнос его страны, если дела пойдут в сторону создания национального колледжа обороны БиГ. Обоснованно можно предположить, что это изменение позиции было обусловлено, inter alia, докладами в министерство обороны Великобритании офицера, в то время занимавшего пост директора по обучению в ЦПУОПМ. 


\section{Литература}

A Single Army for the 21st Century. Sarajevo: Final Report by the Defense Reform Commission, 2005.

Academic Partnership between PSOTC and Sarajevo University. Sarajevo: Faculty for Political Science, Meeting no. 02-2006, 2006.

Concept of AF BiH Professional Development. Bosnia and Herzegovina, Ministry of Defense, AF BiH Joint Staff, 2010.

Drewienkiewicz, John. A Concept paper on the shaping of Higher Military Education submitted to the working group group established by Decision of the Bosnia and Herzegovina MoD., 2008.

Drewienkiewicz, John. Strawman Paper on Professional Officer Development and Training in the Armed Forces of Bosnia and Herzegovina. Sarajevo : NATO HQ, 2009.

Future Individual Officer Education and Training in the AF BiH - A Concept Paper. DRC Team 2, 2005.

Introductory Document on the Professional Development of Officers and Training in the Armed Forces of Bosnia and Herzegovina. A Document written for the Ministry of Defense of $\mathrm{BiH}, 2009$.

Koncept profesionalnog razvoja časnika OS BiH. Bosnia and Herzegovina, Ministry of Defense, AF BiH Joint Staff, 2011.

Lamballe, Alain. Training of Officers of the Armed Forces in Bosnia and Herzegovina and of Civilians on Defence and Security Issues. Sarajevo: Mission in Bosnia and Herzegovina for Military Academic Institutions, 2002.

Lindsay, Ken. Memorandum on Military Education and Doctrine in the AF BiH. NATO Transition Management Group, 2007.

Report of the U.K. Services Command and Staff College in 2001., 2001.

Study into the Feasibility of Establishing a Joint Leadership College for the Armed Forces in Bosnia and Herzegovina . Joint Services Command and Staff College, 2002.

The Way to Partnership for Peace. Sarajevo: Defense Reform Commission, 2003. 